\title{
Gender, Globalisation and Development: A re-evaluation of the Nature of Women's Global Work
}

\begin{abstract}
Though women remain under-represented amongst expatriate managers due to a range of organisational and cultural barriers in selection and individual relocation concerns, they have begun to pursue alternative routes toward a global career such as frequent travel and undertaking domestic positions with international development and community development responsibilities. In this paper we explore the perceptions that Middle Eastern and North American women have of traditional and new trajectories in global work and careers and conclude that increased flexibility allows women to pursue global development opportunities differently throughout their lifetime careers; permitting them to adapt to work-life circumstances. Thus, our research provides new insights into the nature and dynamic of the nature of women's global work and careers.
\end{abstract}

Key words: global careers, North America, Middle East, development organizations, women

\section{Introduction}

Though research has suggested a declining interest from employees in taking traditional expatriate international assignments, there is also evidence of greater mobility in worldwide labour (Grant, 2008) as organisations are increasingly utilising alternative forms of international assignments including fly in/fly out project work, commuter assignments, short-term international assignments and domestic-based jobs which entail international content and/or require an amount of international business travel (Meyskens, 2009; Tharenou, 2005; Welch, Welch \& Worm, 2007; Welch, Worm \& Fenwick, 2003). To date there is limited research exploring how these new forms of work are being viewed by management in the context of global careers or the extent to which they are less disruptive to global employees' lives than traditional expatriate assignments (Collings, Scullion \& Morley, 2007; Thomas, Lazarova \& Inkson, 2005). Nor is there clear understanding as to whether women employees, in particular, view this as a preferable way of attaining global skills while also maintaining work-life balance 
(Metcalfe, 2008). Further, research has yet to explore whether different forms of global work may make less significant identified barriers to women's global opportunities.

Though women's participation as expatriates has greatly increased in recent years, they still remain under-represented at around 20\% of international assignees (Brookfield, 2009) with more women being posted from the Americas, Europe and parts of the Asia Pacific than Japan which still has $98 \%$ of its expatriates being male (ORC, 2008). There are no clear statistics available on women's employment in newer forms of global work. The research that has been undertaken on women in international management focuses overwhelmingly on women from Western countries and on traditional expatriate assignments. We know little about whether the barriers, be they individual, organisational or host country, are the same for women from developing countries. Moreover, we lack knowledge of whether women's perception of global careers are the same for expatriate assignments as for domestic-based jobs with global responsibilities and the perceptions of these differing types of global work for work-life balance.

Thus, this research is significant in that, in examining women's perceptions of the development challenges and opportunities and implications for work/life balance presented by varying forms of international assignments and global work including traditional expatriate assignments as well as domestic work with global work components, it provides a broader understanding of the nature of global careers for women than has been previously considered in the literature on women in international work. Further, this research is important in that it broadens extant research into women's global careers from a predominant focus on Western women to an examination of the perspectives of women from the Middle East and considers whether women from culturally-distant business environments differ in their understanding of challenges and opportunities of international assignments and global work. 
This research supports a growing interest among international scholars to examine and compare women managers' careers across under-represented countries (Burke, 2001; Lirio et al., 2007). The rationale for choosing the Middle Eastern region was based on it being increasingly economically and strategically significant in world affairs as well as there being need for further analysis of women's position in business. Within the Arab Middle East there are many cultural and social practices that continue to discriminate against and disadvantage women in the workplace, with the labour market participation rate being the lowest in the world (UNIFEM, cited in Metcalfe, 2008), career advancement being hindered by work/family conflict, and lack of equality frameworks in organisations even though there has been a growth in women's work in private businesses, professional women's associations, and in the non-government sector (Metcalfe, 2006; Hutchings, Metcalfe, \& Cooper, 2010). Within the Arab Middle East there is great economic, political and social diversity - these differences have been relatively neglected in discussions of women's role primarily because across the region fundamental to understanding the role of women is the Islamic Gender Order and the Qu'ranic view of men and women as 'equal but different' and women primarily as wives and mothers first (Metcalfe, 2006). Irrespective of this, the education of women, positions in management, ability to drive and vote, and restrictions on dress vary markedly across countries. The rationale for comparing the Middle East with North America is because the predominant focus of discussion within the literature on women in international management has been on Western women (primarily North American) working both within the West as well as in developing economies and hence it is salient to analyse the differences between the experiences of Middle Eastern and North American women in new forms of global work. 


\section{Literature review}

\section{The changing nature of international assignments and global work}

Research has suggested that organisations are working to reduce the number of people taking international $^{1}$ assignments due to increasing compensation packages and associated costs (Perez \& Pla-Barber, 2005). This is being done through localising those who are on existing international assignments as well as replacing returned expatriates with local, host country managers or locally-recruited self-initiated expatriates. Additionally, it is suggested that the number of people available to work as expatriates is also declining as people choose not to relocate internationally for long-term positions because of concerns about increased global security/terrorism, lack of belief in career advancement from expatriation, increased costs of living in foreign locations, as well as difficulties associated with dual-career issues and concerns for family interests (Hippler, 2009). Responding to such organisational and employee issues as well as the changing nature of work, organisations are increasingly utilising alternative forms of international assignments including fly in/fly out project work, commuter assignments or domestic-based jobs with international business travel, virtual international assignments or teleworking, and short-term international assignments of a few weeks or months (see Meyskens, 2009; Welch, Welch \& Worm, 2007; Welch, Worm \& Fenwick, 2003). There are calls for a new definition of expatriation which considers the different types of expatriates and their approaches to the international experience, such as those which Siljanen and Lamsa (2009) refer to as: global careerists, balanced experts, idealisers, and/or drifters. Tharenou (2005) refers to domestic work

\footnotetext{
${ }^{1}$ Throughout, where authors specifically refer to 'international' work/jobs we employ this term; otherwise 'global' is used.
} 
which has international responsibilities (such as overseeing international operations or developing business networks abroad), and identified that the major reasons for taking up domestic-based international work are money, professional development and challenging content and reasons which they may not do so include family commitments and disruption.

As a result of economic and financial conditions worldwide in 2008-2010 many organisations downsized globally (Tarique \& Schuler, 2010) repatriating many of their international managers; resulting in a talent surplus. A growing body of literature has begun to explore how to manage talent globally. Though Collings, Scullion and Dowling (2009) say that the term lacks definition and empirical research and it needs to be linked more effectively to overall organisational strategy, a range of literature is exploring the need to consider global employment synergistically to link human capital to organisational strategic goals through attraction, development and retention of those with high levels of human capital (Tarique and Schuler, 2009). Women continue to be an under-utilised source of talent globally as they remain under-represented relative to their male counterparts. Yet, discussions of talent management have not systematically addressed women in global work, nor has the literature on women in international management focused on talent management - rather the latter has tended to explore women's international employment through individual human resource management practices of selection and training rather than undertaking a HR systems approach to attraction, development and retention. Research on talent management in a domestic context has questioned whether programs should be made available to all groups or select individuals who are under-represented and need to be targeted for development (Harris \& Foster, 2010). Given earlier research on women in international management suggesting that there is discrimination against women in 
selection for global assignments, it could well be argued that global talent management programs should increasingly be structured to purposefully target women.

Moreover, current conceptions of international assignment work fail to capture the entirety of labour exchange relations in a diverse global economy. The forgoing discussion constructs work as that performed in formal market systems and ignores other work categories, such as international voluntary and aid work, for example non-government organisation (NGO) management, and also what is termed 'development management work', being associated with the management of development and reconstruction projects in less developed economies with international organisations such as the International Labour Organisation (ILO) and United Nations(UN). We suggest that current scholarship on expatriation and global work is limited in that it tends to focus on men and women in neo-liberal advanced democracies. Given the increasing development and globalisation of Middle Eastern markets, it is a highly relevant time to review whether women's experiences in North America and the Middle East share similarities.

\section{Barriers to women's global work}

In their review of research on women and international assignments, Altman and Shortland (2008) suggest that from 1980 to the present day research has focused on three key themes: 1) the motivations of individual women to take international assignments, 2) organisational policies which may limit women's opportunities for international assignments, and 3) the perceived impact of the host country environment on women's suitability for international assignments. Altman and Shortland (2008) further suggest that these barriers are informed, predicated and reinforced by organisational and societal conventions identified in earlier research such as lack of women mentors and role models, limited female organisational networking, and lack of social 
support. Landmark research by Adler (1984a, 1984b, 1984c, 1987, 1994a, 1994b) provided the foundation for studies of women in international management and attributed the underrepresentation of women to three principle forces: 1) complexities of prejudice in the foreign location, 2) long standing corporate resistance, and 3) misperceptions about disinterest among female managers. More recent research has also suggested that a lack of support (organisational, network or social/family) and work-family conflicts are also barriers to women's international work (Linehan, 2000; Linehan, Scullion \& Walsh, 2001).

\section{Complexities of prejudice in the foreign location}

It has been argued that foreigner prejudice in host country locations makes for ineffective international management (Adler, 1994a). Yet Adler (1994b) found women citing benefits of visibility from being female and that some women reported foreigners reacting to them first as representatives of a company, next as a citizen from where they originate, and only then as women (Caligiuri, Joshi \& Lazarova, 1999; Stroh, Varma \& Valy-Durbin, 2000). Research by Sinagil and Ones (2001) concluded that men and women expatriates were rated quite similarly in terms of job performance, and that employing more women in the global workforce would enhance workforce diversity and build inclusiveness into expatriate assignments. However, Lowe, Downes \& Kroeck (1999) found that women were more resistant than men to work in particular international locations fearing that they would experience prejudice. 


\section{Long-standing corporate resistance}

Adler (1984a, 1984b) suggested that a majority of disadvantages experienced by female expatriates involved a lack of organisational support (Adler, 1984a, 1984b) in the form of: male colleagues' perceptions of, and an unsupportive corporate attitude towards female expatriates. Like Harris and Brewster's (1999) research on the 'coffee machine selection' process, Menzies (2009) suggests that not all organisations have formal selection processes and informal processes, such as tapping people on the shoulder, tend to favour men as the 'old boys' network choose people similar to themselves. Thus, Menzies (2009) argues that without formal selection processes, managers are not required to select the best person for the job. In so doing, however, organisations are under-utilising women as a potential source of talent for organisations (see also Harris, 2001; Linehan, Scullion \& Walsh, 2001). Research indicating a 'glass border', has suggested that there are ongoing assumptions about women as managers and their availability, suitability and preferences for international assignments (Forster, 1999; Linehan \& Walsh, 1999).

\section{Misperceptions about disinterest among women managers}

Despite early research by Adler (1986) showing women MBAs equally interested in pursuing international assignments in their career, it has been purported by some that women are not as interested in pursuing expatriate positions as men (Sinangil \& Ones, 2001). Stroh, Varma \& Valy-Durbin, (2000) found, however, that women are interested in and are apt to accept expatriate assignments abroad as frequently as males, if they did not have children. Where women indicated reluctance to take international assignments, it was not due to lack of interest in the assignment itself, but for family and broader social or community obligations (see Stroh, 
Varma \& Valy-Durbin, 2000) as well as the gendered nature of their domestic and global career development and opportunities (Tharenou, 2008).

\section{Lack of organisational and social support}

A lack of social network support available to women expatriates has also been identified as a significant barrier to women's global opportunities (Linehan, 2000; Linehan, Scullion \& Walsh, 2001) and their willingness to take further international assignments following a negative experience (Hutchings, French \& Hatcher, 2008). It has been argued that mentoring can create competitive advantage for female global managers (Harvey, McIntyre, Thompson Heames \& Moeller, 2009), though Selmer and Leung (2002) found that career development activities and mentoring arrangements were generally less available to female expatriates (see also Linehan, Scullion \& Walsh, 2001). Linehan and Scullion (2008) suggest that women are disadvantaged in that they tend to be excluded from informal interactions of mentoring and networking, even though earlier research has suggested that mentoring relationships are essential for women given the barriers (organisational, interpersonal and individual) they face to advancement. Women are also disadvantaged in international work in that as there are smaller numbers of women working internationally there are less women available to act as mentors for those who are selected for international assignments. Further it has been suggested that much informal networking occurs in global communities through sports associations and clubs which women often do not feel comfortable frequenting (see Hutchings, French, Hatcher, 2008). Yet, the forgoing assessment constructs barriers that are generally relevant to Western working women, and does not explicitly explore the complexities of women's work experiences in different cultures, which may have very different governance and institutional regimes, such as in the Islamic Middle East states. 


\section{Women, Work and Culture in the Middle East}

Metcalfe $(2006 ; 2007 ; 2008 ; 2010)$ suggests that gender has tended to be ignored as a category of social analysis in work in the Middle East; where women's work is examined it focuses primarily on political participation and women's role in the family. However, greater consideration needs to be given to the cultural barriers that impact on career development and the dynamics of the Islamic ethical framework for gender relations. Metcalfe $(2006 ; 2007 ; 2008)$ refers to the Islamic Gender Order which is based on sexual differences and recognises that men and women have different economic and social roles. Thus, gender hierarchies are firmly embedded in everyday cultural and organisational practices. The Qur'an makes explicit a commitment to 'essentalising' differences between men and women. Consequently, there are many cultural and social practices that discriminate and disadvantage women in the workplace, although these are differently interpreted and implemented across Middle Eastern Islamic states depending on the nature of Islamic jurisprudence that is followed. Al-Lamky (2007) suggests that in the Arabian Gulf societies, recently described as "bastions of patriarchy and male chauvinism" (Abdy, 2005; cited in Al-Lamky, 2007), it is widely believed that women's place is primarily at home and if professionally inclined, their participation is expected to be in the areas of education, health (mainly nurses) and other support or clerical jobs largely at the lower end of organisational hierarchies. Leadership positions are typically reserved for men. Yet, it is also essential to avoid generalisations which ignore vast social, economic and political diversity throughout the region. Despite diversity across the region, Middle Eastern women are increasingly highly educated, are gaining greater political influence, are becoming much more entrepreneurial and engaged in institutional capacity building, and are undertaking important 
roles in international non-government organisations (Hutchings, Metcalfe, \& Cooper, 2010). However, it is important to note that women's advances in the Middle East have been assisted by an army of service and domestic workers, primarily from Bangladesh, India and Indonesia who are engaged as nannies, housemaids and drivers (Metcalfe and Rees, 2010).

\section{New choices in global work for women}

Early research has proffered that women may utilise their skills in balancing work and family in international assignments that are not fixed postings but rather offer a degree of flexpatriation (Mayerhofer, Hartmann, \& Mitchell, cited in Altman \& Shortland, 2008). While it has been argued that long-term expatriate assignments may not be a suitable option for women because of family commitments and dual-career issues, global experience may be achieved through global work in the form of fly in/fly out or commuter assignments. These have been argued to allow employees to develop global skills without uprooting the employee's family and personal life (Collings, Scullion \& Morley, 2007). However, it has also been argued that frequent international business travel may be in conflict with work-life balance and can prove difficult over the longer term (Welch, Welch \& Worm, 2007) as research suggests that women continue to be responsible for the majority of the care of the home and family (Crompton, 2006). Tharenou (2008) challenges dominant thinking about women's willingness to expatriate by demonstrating that women are willing to expatriate, but family factors (particularly for women with children) lead to women being less able to transform such willingness into global work than men. It has been suggested that support mechanisms need to be in place for those employees in dual-career couples to take on expatriate assignments (Moore, 2002) as well as short-term international assignments and that both single and married assignees have family-related 
concerns (Starr \& Currie, 2009). Yet, it could also be argued that the higher compensation offered by work with a global component may provide women with more opportunities to pay for assistance with household and care giving responsibilities and better facilitate their work-life balance than would be achieved in a solely domestic work situation. Also, irregular international business travel might synch better at particular points within the career juncture than the traditional expatriate long-term international assignment, allowing women to gain valuable global experience while also maintaining family routines.

Thus, in exploring women's views about the varying types of work involved in global careers, this research examines:

- RQ1: What challenges are perceived for women undertaking international assignments and engaging in various forms of global work?

- RQ2: What opportunities are perceived for women undertaking international assignments and engaging in various forms of global work?

\section{Methods}

This research is based on North American and Middle Eastern women, including those who have experience as expatriates and/or as global managers and others with no prior international/global experience. The results were drawn from qualitative questions which were part of a larger survey (for the Middle Eastern respondents) and as part of qualitative interviews (for the North American respondents). While the data was collected at two different points in time and formed part of larger studies, the issues raised herein are drawn from similar questions asked in relation to challenges and opportunities. The Middle Eastern data was collected by authors one and three while the North American data was collected by author two. 


\section{Procedure and sample}

The Middle Eastern data reports findings from qualitative open-ended questions in a survey conducted from August-December 2007. Respondents to the open-ended questions included 77 middle- and senior-level female managers in Bahrain, Egypt, Jordan, the Kingdom of Saudi Arabia (KSA), Oman, Qatar, and the United Arab Emirates, countries which represent the diversity of economic and political development within the region and include nations which are strongly Islamic fundamentalist (KSA) as well as much more liberal and internationalised (the UAE). The questionnaire and open-ended questions were developed in English, and was largely administered in English to female managers, many of whom also work in international organisations which have English as their working language. For some respondents ( 25 in total) the questionnaire was translated and back translated into Arabic by a research assistant fluent in Arabic and English. The questionnaire was administered by email by Arab Middle Eastern business contacts which the third author had acquired during previous consulting and training programs held in the selected countries. The data was also collected from women holding executive positions in the selected Middle Eastern countries who had previously undertaken Masters or PhD studies in the United Kingdom. In this respect it could be argued that the data is slightly skewed in that women who had studied abroad or were involved in executive positions in the Middle East were more likely to be pre-disposed towards undertaking international work. Potential respondents were approached by the third author through a database held at the author's university as well as databases held by consulting organisations in the Middle East. The women were contacted by email and asked to complete the questionnaire and to send their responses electronically without providing any identifying information; these were treated confidentially and relied on voluntary participation. The women were employed across a range of industries 
and occupations, with many employed in public, educational, and non-government organisations as is consistent with general trends in women's work in the region. The majority of respondents are under 35 and married, although only about $40 \%$ have children, and $90 \%$ are university educated.

The North American data includes in-depth interviews conducted face-to-face and by phone with 25 "Global Gen Xers". "Global Gen Xers" are global managers in dual-career families who were born between 1965-1980. The primary method used to recruit study participants was to widely circulate, via e-mail, a one-page study summary to communicate the purpose of the study as well as the characteristics of the participants targeted. This study summary was used across 3 main channels: 1) professional associations and global corporations across the United States and Canada, 2) business and academic groups through on-line social networking sites (e.g LinkedIn), and 3) personal contacts and networks. Global Gen Xers contacted the second author directly or were referred by HR representatives within contacted global organisations.

For this group of interviews an emergent theoretical sampling approach was utilised which allowed sampling participants as the study progressed, "with the aim being to explore the dimensional range or varied conditions along which the properties of concepts vary" (Strauss \& Corbin, 1998:73); data collection was finalised once theoretical saturation was achieved. Interviews with Global Gen Xers were of 1-2 hours duration, and were recorded and transcribed verbatim. The complete sample of Global Gen Xers included 10 male and 15 female managers between 29 and 44 years of age (avg. age = 38) who were Americans living in the US or Canadians living in Canada. In this paper we only report the responses of the female managers. The participants all worked for global organisations across a range of industries and regularly 
conducted business across multiple country boundaries and time zones (e.g. physically through periodic international travel and virtually using information or communication technologies). They had either global or multi-regional responsibilities requiring international travel across a minimum of two other countries than their own. All Global Gen Xers were in dual-career families with at least one child.

For both regions the women were employed across a wide range of industries although in the Middle East over 50\% of women were employed in the public sector and non-government organisations - this is consistent with women's employment within the region and a tendency for there to be greater employment and managerial prospects within these sectors. As such no industry effect can be identified from the data sets.

Comparative sample data for the Middle Eastern and North American women are included in Table 1.

Insert Table 1 about here

\section{Measurement and analysis}

The Middle Eastern component questions were developed for the research based on issues identified in prior literature about women's global employment and Middle Eastern women's perceptions of varying forms of international work in respect to challenges and opportunities presented. The data was manually coded taking a reduction and interpretation approach based on first-level coding start-lists; the collected data was then divided into clusters of topics.

The North American interviews included questions on topics of: global responsibilities (specifically focusing on international travel patterns and use of technology); previous work 
experiences (including expatriate assignments and other global work); assessment of personal career success (objective and subjective) and work-life balance; adaptation of work, personal and family routines to global work; global mobility and lifestyle issues; and navigating two jobs/careers with working globally. The North American data was analysed using NVivo 8.0 software and Excel spreadsheets to manage the data.

Given that the data for the Middle Eastern women was drawn from open-ended questions in a survey and the North American data was drawn from interviews the two sets of data did not map precisely in the same way as would be possible using only quantitative data. Thus, once both sets of data were manually coded separately a cross-data process was undertaken to then find preliminary codes across the two data sets to identify key themes from written and verbal responses. Only the most salient and complementary data was then included in this research and analysed through development of codes which matched with key themes developed in earlier literature (global, organisational, societal) with the addition of the theme of government's role being considered given its particular relevance for developing women's opportunities in the Middle East.

A summary of the data collection and analysis is included in Table 2.

\section{Insert Table 2 about here}

\section{Results}

The findings are presented from the perspective of this cohort of women's perceptions of the challenges they face in undertaking global work and the factors which they believe may provide opportunities to do so. Within these broad parameters consideration is given to the influence of 
the global context, societal issues within the women's own home countries, the role of government in their home countries, and the role of organisations both domestically and globally. Direct quotes from respondents are included where informative and are representative of the cohort. Quotes from Middle Eastern women are referred to by their country of citizenship and the order in which the survey was received e.g. Oman7. Quotes from North American women are referred to by their being Global Gen Xers, their country of citizenship, and the order in which the interviewees were conducted e.g. GGXUS24. Tables 3 presents a summary of the key themes identified by North American and Middle Eastern women. Given that the sample size from the North American interviewees is considerably smaller than that from the Middle Eastern respondents, the North American data has not been considered in terms of number/percentage of respondents indicating particular themes. Yet, throughout the results and discussion qualitative assessment is made of themes that were important for either or both groups of respondents.

Insert Table 3 about here

\section{Challenges - Global}

\section{Limited awareness of global opportunities}

A major obstacle confronting Middle Eastern women in the pursuit of global work is a lack of awareness of potential opportunities available. While Middle Eastern women are increasingly being represented in non-government organisations and international agencies, one respondent argued that a lack of public education about international work (Jordan2) prevented women from recognising the wide range of global work available including long-term international assignments as well as short sojourns and flexpatriate work. Arguably as more Middle Eastern 
women receive an education in Western countries, however, their knowledge of the range of global possibilities will expand.

\section{Discrimination from the perspective of other countries}

The Middle Eastern women also said that they believed they faced discrimination based on their cultural and religious practices which limited their international employment opportunities. This is reflected in dominant international discourses that permeate about Islam, the Middle East and women's oppression (Metcalfe, 2008). While one respondent suggested that negative cultural perceptions of women based on their religion (Oman37) affected opportunities, another strongly argued that foreign managers preferred foreigners (e.g. Westerners) rather than Middle Easterners for international assignments (UAE17). Yet, another woman claimed that she had applied for academic/professional positions in many educational institutes in a Western country, but had repeatedly been turned down, which she thought reflected being from the Arab world (Bahrain2). Interestingly, other Middle Eastern women suggested that international assignments were more attractive than remaining in the Arab world because women were seen to have good rights and are treated well internationally compared to at home (Jordan37). However, it was also argued that while a long-term international assignment was an attractive option, undertaking domestic work with a global component would be more challenging because it would necessitate balancing their lives across two cultures with quite distinct demands.

\section{Challenges - Societal}

Stereotypes about women and their capabilities 
While North American women said that their global work prospects were challenged by a need to maintain work-life balance, Middle Eastern women also said that their global opportunities were constrained by stereotyping within the Middle East in respect to women's perceived capabilities to handle the demands of international assignments and global work. Consistent with the different roles expected of men and women, respondents suggested that women were often perceived as being weak and not able to handle sophisticated tasks and needing to be taken care of by men (Jordan18). This situation is reinforced by Middle Eastern women being considered as role givers first and foremost and encouraged to be home keepers and have children. We see the women actively engaged in the domestic workforce throughout the Middle East and encouraged to undertake careers before marrying and having children. Yet, undertaking work with a global component would be regarded as being really only suitable for single women because "mothers are expected to focus on their children first and careers second' (Jordan37). While some women mentioned that their husbands and families did encourage them to pursue global work either on a long-term basis or as flexpatriates or frequent international business travellers, one respondent remarked that

Not all families are supportive of women working internationally. The Sheikh needs to do more to encourage women's roles in families as more than a mother..... we are intelligent, have business skills and usually more qualifications than many men. Women can lead the international development process. More rights need to be given to women's NGO's who play a crucial role in supporting women's development (Oman16). 
Lack of recognition of cultural constraints on women's workforce participation and professional socialisation

Associated with stereotyping within the Middle East is a general lack of recognition of constraints upon the type of work which women may perform which then directly affects their selection for international assignments and global work. Respondents noted that, for example, in KSA and Qatar, women are barred from certain professions, including engineering, law and architectural subjects and that most Gulf states have limitations on women working shifts or at night. In contrast to their North American counterparts, Middle Eastern women were usually not involved in social work events or international business travel which influenced their selection into international assignments or prospects for domestic promotion leading to more opportunities for global work. One respondent said that "when I was working in the logistics department several years ago my promotion was delayed 3 times because....I refused to attend social events arranged in venues outside the company premises' (Oman7). Networks are usually based on socialising at which much headhunting occurs, which means that women are just not exposed to the same range of opportunities as men. Middle Eastern women who have undertaken international assignments say that cultural constraints on them also cross international borders. As one respondent noted, 'in Germany, for my surprise, the evaluation for some teachers depended on who used to go out with them for beer' (Jordan15) and given that Arab women neither drink alcohol nor engage in after hours work socialising for cultural reasons, their promotion prospects are limited. Further, while in North America women's increasing education has translated into a broader range of employment in terms of occupations, industries and management roles, for Arab women education, including international education, may just be a tool to enhance their marriage prospects. 


\section{Women's caring responsibilities}

A majority of Middle Eastern respondents noted that it was very difficult to juggle global work commitments around caring responsibilities for husbands, children, elderly parents, and extended family. North American interviewees also expressed concern over the challenges associated with work commitments and child rearing as well as how they could undertake global work when their husbands also had jobs with global work components, particularly when he may travel even more frequently. In the majority of cases, the decision about whether or not a woman undertook global work depended upon whether the husband's career was viewed as primary (be this based on salary and economic contribution to the family, status, or gender roles) or there being an existence of career peers. However, even when both members of the couple were regarded as being career peers, both North American and Middle Eastern women expressed the view that an unequal distribution of labour in the home meant that child care responsibilities fell mostly on women and that global work for women needed to be in synch with the spouse's career and other family commitments. Thus, for married women across the countries, the choice to undertake global work is dependent upon family stage (e.g. planning a pregnancy, children's ages). One interviewee noted that

if a really great opportunity came up that had good education for my son and the [coming baby], that we had a stable life and we had a lot of stuff that we have here and access to family, I think it would be something we would consider.... a couple of opportunities have come up for either moving to Beijing or to Bangkok for a year....the timing wasn't right...my son was very young and then my husband had 
just started a new job and so we'd talked about that and said, 'This is not really good timing for that, but we'll keep it in the back burner'(GGXUS3).

Women in the Middle East and North American noted that short-term international assignments or global work with frequent flying responsibilities placed considerable stress on the spouse/partner remaining at home. While Middle Eastern women did feel this was possible with supportive extended families assisting with childcare (e.g. grandparents, cousins), North American women said that relocating for work meant no family living close by and a loss of supportive care networks such as close neighbours and friends. Several of the North American women said that they took the burden upon themselves to arrange things ahead of time to make things easier for their husbands (e.g. doing laundry or preparing meals for the week while they were gone). As one interviewee stated

I am kind of always on call. When I have a trip coming up, I have to get my home prepared. I do this by making all the meals for the week ahead of time and label them for my family. I do laundry on the weekend in advance. All this is so it's not so difficult on the one parent [left] (GGXCanada18).

North American women also said that they tried to make it easier on the children by keeping up with their routines while on the road traveling (e.g. calling home to read a bedtime story) and packing their schedules as much as possible while abroad so that they could get back home in the shortest time possible. One interviewee said

my one daughter who is twelve now, she used to be sad when I had to go on a trip and we would, she'd pick out a book, put it in my suitcase and I would still read to 
her at night...So we would do stuff like that and if we forgot to do that, then our agreement was I would buy a book while I was there and bring it home to give to her (GGXUS23).

Interestingly, like some Middle Eastern respondents, some of the North American interviewees said that occasionally people in society might not understand or think it strange that the mother travels so much and/or to foreign places, but her immediate family's perception of her career and family were what mattered most. As one interviewee remarked, 'you know, people's perceptions are, whatever they think but it's really the relationship within your own family that [matters]' (GGXCanada11).

\section{Challenges - Organisational}

\section{Gendered selection, training and pay within organisations}

Middle Eastern women said that societal expectations and stereotyping were reinforced by organisational practices which discriminated against them in respect to selection, training and pay for international assignments and global work. One respondent remarked that 'any international courses, whether it was through my work or through the civil services affairs, it is always males who are considered' (Jordan25). The suggestion was that usually only men were considered for international training courses, conferences or short postings as organisations reflected broader societal views that a woman's role is primarily one of being a family support. Even short-term international assignments were seen as conflicting with women's caring duties. In many instances salary scales for global work are based on gender with a respondent claiming the need to develop 'salary scales based on skills and performance rather than gender (KSA1). In 
regard to virtual global work it was also suggested that Arab women would have difficulties with this because of organisational perceptions of international stereotyping based on Arab women's dress (e.g. burqa, abaya, niqab, hijab). Yet some women suggested that engaging in teleconferencing with colleagues in other countries outside of the Middle East would help redress discrimination through breaking down stereotypes of religion based on limited knowledge of Arab women's cultural values. One respondent suggested that Middle Eastern organisations were short-sighted in having such a view of global collaboration and argued that 'international firms....have a great HR system... [and the] rights of [the] employee is protected.... So, I have not experienced unfair treatment working internationally' (KSA1).

While North American women did not suggest actual discrimination in selection for international assignments, they did express that the process is not clearly outlined with global organisations lacking talent databases or company-wide systems for accessing data on those with requisite global skills. The process seemed to be "word of mouth" in being 'found" for an assignment - with managers discussing with each other who they thought would be good for a job. The formal process in most cases was represented by indicating on performance reviews and career planning documents that certain employees were interested in pursuing long-term international assignments in their careers - but the process for selecting individuals for other forms of global work seemed less clear. Several of the North American interviewees also said that their opportunities were constrained by less involvement in networking than their male colleagues. Some women said that there are particular fields of work where visibility - being onsite or in the office or networking is a key factor in gaining good assignments, projects or client work. Thus, it can be argued that women who choose to undertake virtual global work or 
teleworking because of family responsibilities may miss opportunities available to men or women without children.

\section{Mixed organisational support for women with families}

In addition to discriminatory practices, Middle Eastern respondents said that their opportunities were constrained by a lack of organisational support practices to assist women in advancing their careers. One respondent argued that 'maternity leave is now only 70 days and absolutely not even enough... [and there is] no daycare for working mothers"; they critiqued "...hiring women according to their marital status or if they're with children because a lot of companies consider that as a disadvantage!' (Jordan1). Also, several respondents suggested that to ensure women had equal opportunities as men in selection for long-term international assignments, it was necessary for organisations to provide family support to successfully realise the posting. For instance, one respondent said that 'when sending a lady on an international assignment the husband should get the same chance at the same time and place' (Oman12).

Women from the Middle East felt that global jobs in the domestic home location could be more difficult to reconcile with work-family balance than an international posting of several years for which support mechanisms such as full-time nannies/house-keepers are provided by organisations. Respondents from both regions examined in this research noted the challenge of travel-intensive global work. The North American women, however, expressed having more discretion in managing their travel vis-à-vis family needs than the Middle Eastern women. This discretion helped greatly in achieving desired levels of work-life balance. Echoing several other women, one respondent talked about the flexibility in her organisation 
I mean if I say I can't travel that week--it's my daughter's birthday--nobody seems to resent that (if they do they don't tell me) and we either reschedule or I get to have a pass on that trip or whatever (GGXUS23).

And others talked about the organisational practice of using technology to replace periodic international travel for work.

There's less travel right now. Within North America, we do a lot of IMing (instant messenger)...Otherwise...we many times are directly on the phone or web conferencing...We're doing less and less travel, more other type of communication [for] convenience and efficiency...for personal reasons, [I] try to avoid travel when I can (GGXUS21).

Yet even given this organisational flexibility, some North American women felt they might be stigmatised in the organisation as not being as career focused because of their family responsibilities. As one interviewee observed

I do think that with our generation people choose women or men equally....I do think though is that it's still the case that women face different issues in the workplace. Different social pressures....I mean you still face stereotypes.... with my pregnancy and the fact that I'm having a third child my personal life is on display and up for comments....nobody comments on the guy sitting next to me who has three kids who's keeping quiet....nobody forms any sort of judgment against him...you can more often consider that person to still have a successful career 'cause they would be able to balance that. Nobody's questioning him (GGXCanada19). 


\section{Opportunities - Global}

\section{Global career development through international assignments and global work}

Middle Eastern women argued that prior international experience abroad was very beneficial in equipping them with skills to transcend cultural stereotyping from foreign colleagues or organisations, as was being educated in the West. Further, Middle Eastern women suggested that having governments who had strong links with international organisations and non-government agencies would also increase women's opportunities to engage in global employment. While one respondent remarked that, 'government and organisational support for international linkages with international institutions and organisations helps women' (Jordan11), another said that it was also critical to have 'representation of Middle Eastern women on international boards and committees' (Jordan26) to raise their profile and belief about suitability for a wide range of global work. Yet, it was also acknowledged that providing opportunities was not sufficient in itself; there also needed to be government action to work with organisations to provide support for women to balance their caring responsibilities.

While North American women suggested that there was not direct discrimination in selection for international assignments and global work, the criteria for selection were often not clearly outlined or advertised. Thus, they suggested that to be equally considered for international assignments and varying types of global work as their male colleagues, it helped that they openly expressed to their managers that they were interested in global opportunities. One interviewee said that 'if you don't state it and you don't ask for it, nobody will know and you'll never get it...I'm pretty [open] and I have a very good relationship with my boss so I'm 
very direct with her about where I feel I'm at, what I've done [and] what I wanna do' (GGXUS24).

\section{Opportunities - Societal}

Strong female role models in society

The Middle Eastern women highlighted the need for a change in societal views if women were to have better opportunities to engage in global work. Many respondents identified the critical role of government in increasing women's political representation which would provide women with the opportunity to influence government legislation and provide mechanisms that allowed Middle Eastern women to work internationally, either on an international assignment abroad or doing global work based domestically. In addition to increasing the number of strong female role models at a political level, there is also a need for women to have role models in industry. Having organisational exposure to other Middle Eastern women who have studied or worked abroad will provide them with knowledge of the range of global possibilities available to them. One respondent advocated this, saying that 'the biggest issue I saw in my working experience was when our own organisations bring in specialists who are women and believe in their abilities and treat them professionally' (Jordan15).

Yet, it is also worth noting that Middle Eastern women's opportunities were not distributed equally--women from well-connected, wealthy or prominent families had created more opportunities than those that were less privileged. One respondent confirmed, 'it's all dependent on personal connections" (Jordan 35). Several respondents proffered that while there may be more recruitment, training and promotion opportunities for men, women who come from wealthy families may actually be able to find global opportunities irrespective of women 
generally receiving less support from human resource functional areas. This suggests that class may be as important as gender in determining access to global opportunities - or at the very least that there is a strong inter-relationship between class and gender across Arab societies.

\section{Support from families}

Both North American and Middle Eastern women suggested that having the support of their spouse and extended family would facilitate global career opportunities. While the Middle Eastern respondents suggested that the man's career was the primary driver within a family, the North American interviewees suggested a mutual understanding that global career opportunities did not depend solely upon the man (or woman) and the majority of husbands seemed willing to synch their careers with their wives opportunities. In a few cases, some even might scale back their own careers for their wives' opportunities to undertake an international assignment. One interviewee stated that, 'and that's part of what we talked about; he [my husband] would be willing to make a sacrifice, if we both together thought it was best for the family' (GGXUS23).

Importantly, some of the North American interviewees also highlighted the cultural value of international assignments for the children and stressed that support from a spouse and family members could provide developmental opportunities for careers as well as social growth for the whole family. One American interviewee said,

we would ideally like for [our daughter] to be [abroad] for some, and the [coming baby] for some period of their education....if it ends up just being Canada that still counts...the two candidates right now are Vancouver and Ottawa, "cause [my husband's company] has an office in Ottawa, which makes it a possibility for him....So the challenge is can we make it a career move such that, for example, I 
have a three year gig in France, that's ideal. If that can't happen then we may evaluate taking a year off from work and going and living in Italy for a year...and then coming back and reestablishing ourselves in San Francisco (GGXUS24).

\section{Opportunities - Government}

\section{Government legislation and support for women at work}

Middle Eastern respondents referred to the need to have government legislation to assist women's domestic employment opportunities which they viewed as fundamental to providing a foundation from which women would then be able to access international employment. They referred to the need for: strict regulations regarding sexual bias (Jordan18), anti-sexual harassment policies (KSA6), and diversity quotas (Qatar78).

Middle Eastern women also identified the need to have more government training to develop women as future leaders and 'committees to provide support for women' (Jordan29), although they acknowledged that efforts were being made in this direction, particularly in the Emirates and Jordan. One respondent said,

We need to maintain Shar'iah law...but women have the right to work in caring and community roles and these require international exchanges, and leadership roles. There are now many women entrepreneurs and with help from their families they have been successful. But for business to grow there needs to more acceptance that women must work across cultures. More women should be given government representative roles so we can allow women's voices to be heard. ... women also can have a key role in economic and international development....women's representation should also be on shura councils.... yes we have business rights but 
we still need more voice in political institutions......... the Sheikh should create more frameworks to allow women's representation in government bodies (Oman16)

\section{Opportunities - Organisational}

Organisational support for women at work

While the Middle Eastern women felt there was a need for government to implement protective legislation for bringing employment conditions on par with developed country standards, there was also a need for organisations to provide supportive strategies to assist women in managing work-life balance when abroad and doing global work domestically. Identified strategies included: teleworking and virtual global work (Jordan27); flexi-hours, working from home and part-time work options (Egypt20); buy-in of women in leadership positions through executive opportunities to lead committees (Qatar78); a quota system for women for global positions (Oman16); having cross-cultural exchanges of female employees across various countries (Jordan25); and a clear, human resources plan advocating a wide and long-term vision for women with an articulated managerial career ladder (Jordan 25). Additionally, respondents mentioned the need for women to have admittance to male-dominated networks in foreign subsidiaries and opportunities to work with international clients on cross-cultural exchanges. A Saudi respondent summed up the views of many in arguing that,

working women should have access to management training and line experience, mentors and role models at the highest levels...Admittance to formal and informal networks and channels of communication at work....Providing all women with female mentors in order to provide support and guidance within a system that is still 
dominated by men....changing organisational cultures to reflect the needs of working women (KSA6)

The majority of North American interviewees spoke of the need for organisations to support varying types of global work which would assist them to manage work-life balance. The women referred to the need to have global exposure in their careers and cultivate global competencies without having to disrupt their family lives by taking on an international assignment. They stressed their preference for their families to keep their routines and the women accomplishing their global work through traveling internationally and addressing global work flows in the office and/or virtually when in the domestic home location. To this end, the women's organisations were largely flexible in accommodating how the women would combine their global work with their family. As a interviewee commented,

If I'm a mom with a kid trying to be in the office at nine every night it wouldn't work. And so being able to do that from home, and especially if you have VPN connectivity at home, you have Internet and you have high speed, the phone and everything else, there's no reason why you shouldn't. So I think it really has helped to....be able to get people to be able to work globally (GGXUS3).

\section{Organisational training and development}

In addition to implementing practices which support women's ability to undertake differing types of global work and balance it against their family and caring responsibilities, Middle Eastern women also spoke of the need to have a greater level of organisational training. Respondents suggested that if women were to be able to partake in global opportunities they needed to have 
regular inter-cultural training, even if they would only engage with foreign colleagues in a virtual work environment. The need for having trainers from a range of cultures was also identified as being important in breaking down stereotypes and ensuring that women had exposure to a range of people from varying cultures which would facilitate their global interactions. Further, respondents suggested the need to provide international training and seminars with long lead times which accommodated women and in particular to avoid scheduling global work during religious holidays and festivals.

\section{Discussion}

The results suggest that the differing contexts of North America and the Middle East means that the issues raised do not map consistently but do raise significant concerns about factors that continue to impede women's global employment opportunities. Lack of government/legislative support and international perceptions of Middle Eastern women and culture are important factors identified by the Middle Eastern women while organisational and societal/family issues are significant for both Middle Eastern and North American women. Most importantly both cohorts studied in this research highlight the continuing challenges in balancing a global career with family. Whereas North American women stressed that global work performed through international business travel and virtual work allowed them to balance work and family demands and to achieve a global profile, the Middle Eastern women said that due to societal values and lack of government and organisational support it would actually be harder for them to undertake such forms of global work or short-term international assignments, so they would favour traditional long-term postings abroad. Middle Eastern women's global employment opportunities are also affected by cultural and Islamic attitudes to sex roles which means that in many cases 
there is a lack of spouse or family support to assist the women to progress in global careers. Yet, it is interesting to note that some respondents did suggest they had supportive husbands and families and so have been able to undertake an international education and either long-term or short-term international assignments. While there is still resistance for Middle Eastern women to engage in private commercial international work, women would be encouraged to engage in international development and charity work that focused on education and community development, which is valued by Arab communities, and provides the women's family with enhanced status, given the importance for Muslims to demonstrate commitment to the improvement of human well being (see Metcalfe and Rees, 2010). Opportunities for Arab women, however, have grown through women's networks that are flourishing in Egypt and Bahrain specifically.

For the Middle Eastern women, the results support early research in the field about foreigner prejudice (Adler, 1984a; 1984b) even though a belief in foreigner prejudice has long since been discounted in the Western context (Stroh et al., 2000; Sinagil \& Ones, 2001), and was not mentioned by North American respondents in this study. The Middle Eastern women said that they believed they faced discrimination based on their cultural and religious practices which limited their international employment opportunities. This is reflected in dominant international discourses that permeate about Islam, the Middle East and women's oppression (Metcalfe, 2008). The Middle Eastern women did highlight the value of having had prior international experience abroad, an education in the West, or general awareness of global opportunities. Further, while Western women have government/legislative protections against discrimination and harassment, Middle Eastern women's global work opportunities remain constrained by a 
lack of equal opportunity practices (despite an emphasis on education and training for women) which subsequently affects selection for global roles.

Both cohorts suggested that corporate resistance to women's global careers which was identified over two decades ago (Adler, 1984a; 1984b) is still somewhat prevalent. Middle Eastern women said that while they were encouraged by organisations offering more training for women, there is real evidence of organisational discrimination against women in terms of selection for international assignments, a lack of inclusion in aspects of work which might lead to international assignments, and a lack of organisational support for women to balance their careers and families. However, one must bear in mind that corporate resistance is constructrelevant to international multinational corporation work, and not necessarily international aid or charity work which often requires the specific knowledge and expertise of women. Moreover, lack of organisational initiatives around flexible work impede the abilities of Middle Eastern women to engage in global virtual work and other forms of global work which might potentially allow them to balance work against their family lives. While the North American interviewees did not suggest that organisations discriminated against women in selection for varying types of global work and some said that there is no discrimination at all, a large percentage of the interviewees did say that the selection process is not direct and potential opportunities are not always posted, which suggests that there may be some discrimination against women, such as was suggested in earlier research (Harris \& Brewster, 1999; Linehan et al., 2001; Menzies, 2009).

The most salient issue raised was support for early research into women's own concerns about relocating due to family considerations as obstacles to global career development (Adler, 1984a; Sinagil \& Ones, 2001). This highlights consistencies with more recent research 
suggesting that there are difficulties associated with juggling global work with family responsibilities if there is a lack of family, societal and/or organisational support (Harris, 2004; Tharenou, 2008). While recent research in this field has suggested that new types of global work may better facilitate work-life or work-family balance than traditional long-term international assignments (Collings et al., 2007; Mayrhofer et al., 2008, cited in Altman \& Shortland, 2008), our results suggest that this plays out differently for the two cohorts of women in our study. The North American women suggested that they may not be able to easily relocate for a long-term international assignment because of dual-career issues yet the opportunity to do global work based in their domestic home location may better suit their current life stage. For the Middle Eastern women, though, this would be a less appealing option, as culturally it would not be deemed acceptable for mothers to be away from home for evenings or extended periods. For the Middle Eastern women who are viewed primarily as carers, short-term international assignments and international business travel are difficult because of the implications that they would be viewed as being poor mothers and/or wives; thus long-term international assignments would be more viable as it would give them the stability to be continually at home for the family.

However, the forgoing needs to acknowledge the relative advantages of Middle Eastern women's benefits, especially for those working in public administration. Whereas Qatar and KSA and the United Arab Emirates, for example, have limited democratic systems, their provisions for maternity leave for women who do work are far more substantial than their North America counterparts. Typically maternity provisions allows for 1 year full paid leave and a guarantee to the same job on return (Metcalfe, 2008). Yet, the most significant barriers for women in the Middle East are limited legislative frameworks governed by Shar'iah law. 


\section{Conclusions}

\section{Implications for theory - Re-imagining the dynamics of women and global work}

This research makes an important contribution to the literature on expatriation and working globally in that it expands current theoretical understandings of what constitutes global work for women and the associated challenges and opportunities for full spectrum global career engagement. Our re-evaluation of women's global work suggests that long-term international assignments in multinational corporations do not provide a true representation of the changing dynamics of work in a globalised economy. Our analysis provides insights into new categories of global work performed domestically. Further, these new categories reflect the extent to which different types of global work can be balanced against life and family commitments and how global work social constructs change in the light of regional and geographic location. While the research suggests that both North American and Middle Eastern women believe that work-life balance and general social expectations impact on their engagement in global careers generally, there were important differences raised between the two groups. The North Americans highlighted the importance of organisational support, and perhaps due to the individualistic orientation in neo-liberal democracies, did not focus on the importance of government intervention to assist women's development. In contrast, the Middle Eastern women highlighted the constraints imposed by discrimination in the political and economic culture, and stressed the lack of protective government legislation and government support. As argued previously, women's empowerment in the Middle East will not be achieved without new legislative measures to provide additional rights, choices and opportunities. Importantly, family support is viewed as essential in enabling women to take on international roles, and many professionally educated Middle Eastern women are able to take on international assignments due to support 
from both extended families as well as migrant labour. Women's experiences are intertwined with a complex set of social and organising principles, including the nature of work, educations systems, class structures in economies and institutional regimes that govern gender relations.

\section{Implications for management - Creating opportunities for women's career development in the}

\section{global economy}

The results of this research suggest that there are still major challenges for women seeking international careers with single women facing glass borders and women with families also having difficulties in balancing work/family issues. However, the findings also suggest that there are new ways of conceptualising women's participation in the global work arena which may provide opportunities for women to have at least limited participation in global work which may provide a foundation for future prospects. The implications for global human resource systems planning and organisation require intimate knowledge of the institutional and cultural processes prevalent in vastly different geographical locations. The provision and role of childcare for example cannot be assumed to be conceptualised or experienced in the same ways in countries as diverse as those in the Middle East and North America. However, there are policy approaches that would benefit both groups of women. The research is important in highlighting to managers of global workforces the need for organisations to invest more in mentoring of women for global positions and transferring acquired knowledge from those women who have undertaken international assignments and/or global work to those who seek such experiences. Also, organisations need to consider how to offer flexibility in the domestic workspace given a global context, such as by providing job sharing for work with global travel components and intensive work schedules. The research also suggests that organisations need to give specific 
consideration to how they support employees for new types of global work. The variety of gender relations regimes require different policy approaches. There could also be more attention paid by human resource planners to strategise the use of global talent in the organisation by synching global opportunities with employees' life stages and cultural constraints - and considering how to better accommodate women's international work opportunities through talent management programs which recognise women as an under-utilised talent. Last, organisations need to provide tangible supports for spouses/partners of expatriates and global employees in considering cultural factors in how combining work and family is viewed by global workforces.

\section{Limitations and issues for future research}

Despite the strengths of the research in extending knowledge about women's involvement across a range of forms of global opportunities, the research does have some limitations which might be addressed in future research. First, we acknowledge that our analysis has been undertaken in two blocks of North America and the Middle East and that we have not specifically explored in detail the impact the institutional and labour market systems within each of the countries. Future research undertaken with a larger sample size would be further insightful, allowing for analysis of country differences (expected to be somewhat marked within the Middle East particularly). Second, our sample may reflect the bias of a particular group of respondents in that all of the North American interviewees are married and have children and most of the Middle Eastern respondents are married with forty percent having children; accordingly, their views of work-life balance may be different from women who are single or childless. Future research might examine a wider age group and consider how challenges fall differently on women in different life phases. Third, while all of the North American women are currently involved in some form of global work, not all of the Middle Eastern women have worked abroad or globally and hence, 
report their perceptions of obstacles. It would be valuable for future research to study women during and after different types of international assignments and/or global work to see if their views of challenges and opportunities change. Last, as both studies included only the perspectives of the women in partnered relationships, it would be beneficial if future research studied dyads to examine both partners' perspectives of the challenges and opportunities for long-term international assignments and new forms of global work. 


\section{References}

Adler, N. (1984a). 'Women in International Management: Where are They?'. California Management Review, 6: 79-89.

Adler, N. (1984b) 'Expecting International Success: Female Managers Overseas'. Columbia Journal of World Business, 19: 77-83.

Adler, N. (1984c) 'Women Do Not Want International Careers: And Other Myths About International Management'. Organisational Dynamics, 13(2): 66-79.

Adler, N. J. (1986) 'Do MBAs Want International Careers?'. International Journal of Intercultural Relations, 10(3): 277-300.

Adler, N. (1987). 'Pacific Basin Managers: A Gaijin, Not a Woman'.. Human Resource Management, 26: 169-91.

Adler, N. (1994a) 'Competitive Frontiers: Women Managing Across Borders'. Journal of Management Development, 13(2): 24-41.

Adler, N. (1994b). 'Competitive Frontiers: Women Managing Across Borders'. In N. Adler, and D. Izraeli, D. (Eds.), Competitive Frontiers: Women Managers in a Global Economy: 23-42. Oxford: Blackwell. 
Al-Lamky, A. (2007) 'Feminizing leadership in Arab societies: the perspectives of Omani female leaders'. Women in Management Review, 22(1): 49-67.

Altman, Y. and Shortland, S. (2008) 'Women and international assignments: Taking stock - a 25 year review'. Human Resource Management, 47(2): 199-216.

Brookfield Global Relocation Services. (2009) Global Relocation Trends: 2009 Survey Report. Brookfield GRS: Woodridge.

Burke, R.J. (2001) 'Women in management: Cross-cultural research'. Cross Cultural Management, 8(3/4): 35-67.

Caligiuri, P., Joshi, A. and Lazarova, M. (1999) 'Factors Influencing the Adjustment of Women on Global Assignments'. The Journal of Human Resource Management, 10(2): 163-79.

Collings, D.G., Scullion, H., and Dowling, P.J. (2009) 'Global staffing: A review and thematic research agenda', The International Journal of Human Resource Management, 20(6): 12531272.

Collings, D.G., Scullion, H., and Morley, M.J. (2007) 'Changing patterns of global staffing in the multinational enterprise: Challenges to the conventional expatriate assignment and emerging alternatives'. Journal of World Business, 42(2): 198-213. 
Crompton, R. (2006) Employment and the family: The reconfiguration of work and family life in contemporary societies. Cambridge: Cambridge University Press.

Grant, T. (2008) 'Migrants redefining bounds of business'. The Globe and Mail, B3: 24 ${ }^{\text {th }}$ June.

Forster, N. (1999) 'Another 'glass ceiling'? The experiences of women professional and managers on international assignments' Gender, Work and Organization, 6(2): 79-90.

Harris, H. (2001) 'Researching Discrimination in Selection for International Management Assignments: The Role of Repertory Grid Technique' Women in Management Review, 16(3): 118-125.

Harris, H. (2004) 'Global careers: Work-life issues and the adjustment of women international managers'. Journal of Management Development, 23(9): 818-832.

Harris, H. and Brewster, C. (1999) 'The Coffee Machine System: How International Selection Really Works'. International Journal of Human Resource Management, 10(3): 459-76.

Harris, L. and Foster, C. (2010) 'Aligning talent management with approaches to equality and diversity: Challenges for UK public sector managers', Equality, Diversity and Inclusion: An International Journal, 29(5): 422-435. 
Harvey, M., McIntyre, N., Thompson Heames, J., and Moeller, M. (2009) 'Mentoring global female managers in the global marketplace: Traditional, reverse, and reciprocal mentoring'. International Journal of Human Resource Management, 20(6): 1344-1361.

Hippler, T. (2009) 'Why do they go? Empirical evidence of employees' motives for seeking or accepting relocation'. International Journal of Human Resource Management, 20(6), 1381-1401.

Hutchings, K., French, E. and Hatcher, T. (2008) 'Lament of the ignored expatiate: An examination of organisational and social network support for female expatriates in China'. Equal Opportunities International, 27(4): 372-91.

Hutchings, K., Metcalfe, B., and Cooper, B. (2010) 'Exploring Middle Eastern Women's Perceptions of Barriers to, and Facilitators of, International Management Opportunities'. International Journal of Human Resource Management, 21(1): 61-83.

Linehan, M. (2000) Senior Female International Managers: Why So Few?. Vermont: Ashgate Publishing.

Linehan, M., Scullion, H. and Walsh, J. (2001) 'Barriers to Women's Participation in International Management'. European Business Review, 13(1): 10-18. 
Lirio, P., Lituchy, T. R., Monserrat, S. I., Olivas-Lujan, M. R., Duffy, J. A., Fox, S. (2007) 'Exploring career-life success and family social support of successful women in Canada, Argentina and Mexico'. Career Development International, 12: 28-50.

Lowe, K.B., Downes, M. and Kroeck, K.G. (1999) 'The impact of gender and location on the willingness to accept overseas assignments'. International Journal of Human Resource Management, 10(2): 223-234.

Menzies, J.L. (2009) Women in International Assignments in Multinational Enterprises: An Exploration of their Participation. VDM-Verlag: Germany.

Metcalfe, B.D. (2006) 'Exploring Cultural Dimensions of Gender and Management in the Middle East'. Thunderbird International Business Review, 48(1): 93-107.

Metcalfe, B.D. (2007) 'Gender and Human Resource Management in the Middle East'. The International Journal of Human Resource Management, 18(1): 54-74.

Metcalfe, B.D. (2008) “'Women, management and globalization in the Middle East'. Journal of Business Ethics, 83: 85-100. 
Metcalfe, B.D. (2010) 'Reflecting on difference: women, Islamic feminism and development in the Middle East', in J. Sawad and M. Ozgilbin (Eds.), Gender and Diversity Management in Asia: . Cheltenham: Edward Elgar.

Metcalfe, B.D. and Rees, C.J. (2010) 'Gender, globalization and organization: Exploring power, relations and intersections'. Equality, Diversity and Inclusion, 24(1): 5-22

Meyskens, M., Von Glinow, M., Werther, W., and Clarke, L. (2009) 'The paradox of international talent: alternative forms of international assignments' International Journal of Human Resource Management, 20(6): 1439-1450.

Moore, M. J. (2002) 'Same ticket, different trip: Supporting dual-career couples on global assignments'. Women in Management Review, 17(2):61-67.

ORC (Organization Resources Counselors) Global Human Resource Solutions. (2008) Worldwide Survey of International Assignment Policies and Practices. ORC: New York.

Perez, J.B. and Pla-Barber, J. (2005). 'When are international managers a cost effective solution? The rationale of transaction costs economics applied to staffing decisions in MNCs'. International Journal of Human Resource Management, 58: 1320-1329.

Selmer, J. and Leung, A. (2002) 'Career Management Issues of Female Business Expatriates'. Career Development International, 7(6): 348-58. 
Sinangil, H. and Ones, D. (2001) 'Expatriate Management'. In N. Anderson, D. Ones, H. Sinangil, and C. Viswesveran, C. (Eds.), Handbook of Industrial, Work \& Organisational Psychology. London: Sage.

Starr, T.L. and Currie, G. (2009) 'Out of sight but still in the picture: Short-term international assignments and the influential role of family'. International Journal of Human Resource Management, 20(6): 1421-1438.

Strauss, A. and Corbin, J. (1998) Basics of Qualitative Research: Techniques and Procedures for Developing Grounded Theory. $2^{\text {nd }}$ ed., Thousand Oaks, CA, Sage.

Stroh, L., Varma, A. and Valy-Durbin, S. (2000) 'Why are Women Left at Home: Are They Unwilling to go on International Assignments?', Journal of World Business, 35(3): 241-255.

Tarique, I. and Schuler, R.S. (2010) 'Global talent management: literature review, integrative framework, and suggestions for future research', Journal of World Business, 45: 122-133.

Tharenou, P. (2006) 'International work in domestic jobs: an individual explanation'. International Journal of Human Resource Management, 16(4): 475-496.

Tharenou, P. (2008) 'Disruptive decisions to leave home: Gender and family differences in expatriation choices'. Organizational Behavior and Human Decision Processes, 105(2): 183200. 
Thomas, D.C., Lazarova, M.B., and Inkson, K. (2005) 'Global careers: New phenomenon or new perspectives?', Journal of World Business, 40(4): 340-347.

Welch, D.E., Welch, L.S., and Worm, V. (2007) 'The international business traveller: A neglected but strategic human resource'. International Journal of Human Resource Management, 18: $173-183$.

Welch, D.E., Worm, V., and Fenwick, M. (2003) 'Are virtual international assignments feasible?', Management International Review, 43(1): 95-104. 
Table 1: Sample Characteristics

\begin{tabular}{|c|c|c|c|c|c|}
\hline & & $\begin{array}{r}\text { Middle } \\
\text { respo } \\
\end{array}$ & $\begin{array}{l}\text { tern } \\
\text { nts }\end{array}$ & $\begin{array}{r}\text { North A } \\
\text { interv }\end{array}$ & $\begin{array}{l}\text { rican } \\
\text { ees }\end{array}$ \\
\hline & & no. & $\%$ & no. & $\%$ \\
\hline Age & $18-24$ & 13 & 16.88 & 0 & 0.0 \\
\hline & $25-34$ & 25 & 32.46 & 3 & 20.0 \\
\hline & $35-49$ & 27 & 35.06 & 12 & 80.0 \\
\hline & $50-65$ & 2 & 2.59 & 0 & 0.0 \\
\hline Nationality & Bahraini & 4 & 5.19 & & \\
\hline & Omani & 6 & 7.79 & & \\
\hline & Saudi & 15 & 19.48 & & \\
\hline & Jordanian & 45 & 58.44 & & \\
\hline & Egyptian, Emirati, Qatari & 7 & 9.09 & & \\
\hline & United States & & & 9 & 60.0 \\
\hline & Canada & & & 6 & 40.0 \\
\hline Marital status & Single & 37 & 48.05 & 0 & 0.0 \\
\hline & Married & 35 & 45.45 & 15 & 100.0 \\
\hline & Divorced/widowed & 5 & 6.49 & 0 & 0.0 \\
\hline & De-facto partnered & 0 & 0.0 & 0 & 0.0 \\
\hline Dependents & Have children & 31 & 40.25 & 15 & 100.00 \\
\hline & Do not have children & 46 & 59.75 & 0 & 0.0 \\
\hline $\begin{array}{l}\text { Highest } \\
\text { qualification }\end{array}$ & $\begin{array}{l}\text { Postgraduate }(\mathrm{PhD} / \mathrm{MBA} \\
\text { etc ) }\end{array}$ & 27 & 35.06 & 6 & 40.0 \\
\hline & Bachelor's degree & 44 & 57.14 & 9 & 60.0 \\
\hline & Other qualification & 6 & 7.79 & 0 & 0.0 \\
\hline
\end{tabular}


Table 2: Summary of Methods

\begin{tabular}{|l|l|l|}
\hline Access & Middle East & North America \\
\hline & $\begin{array}{l}\text { Pool of survey respondents } \\
\text { developed from databases of } \\
\text { Middle Eastern female } \\
\text { executives held by a UK } \\
\text { university and ME consulting } \\
\text { firms }\end{array}$ & $\begin{array}{l}\text { channels 1) professional } \\
\text { associations and global } \\
\text { corporations across the United } \\
\text { States and Canada, 2) business } \\
\text { and academic groups through } \\
\text { on-line social networking sites } \\
\text { (e.g LinkedIn), and 3) personal } \\
\text { contacts and networks }\end{array}$ \\
\hline Sample & $\begin{array}{l}\text { 25 (10 male, 15 female) } \\
\text { Generation X managers in } \\
\text { dual-career families from } \\
\text { Canada and the USA }\end{array}$ \\
\hline Bahrain, Egypt, Jordan, KSA collection & Oman, Qatar, UAE & $\begin{array}{l}\text { In-depth semi-structured } \\
\text { interviews } \\
\text { Conducted in English }\end{array}$ \\
\hline Analysis within regions & $\begin{array}{l}\text { Open-ended questions } \\
\text { included in survey. } \\
\text { Administered in English and } \\
\text { Arabic }\end{array}$ & $\begin{array}{l}\text { Manually coded } \\
\text { Analysis across regions }\end{array}$ \\
\hline
\end{tabular}




\section{Table 3:}

\section{Summary of Challenges \& Opportunities for Middle East \& North American Women}

\begin{tabular}{|c|c|c|}
\hline CHALLENGES & Type & Description \\
\hline \multirow[t]{2}{*}{ Global } & Limited awareness of global opportunities & Middle Eastern women have less access to information about different global assignments. \\
\hline & $\begin{array}{l}\text { Discrimination from perspective of other } \\
\text { countries }\end{array}$ & $\begin{array}{l}\text { Middle Eastern women are hindered by negative cultural perceptions and preferences for } \\
\text { Westerners in global work assignments. }\end{array}$ \\
\hline \multirow[t]{3}{*}{ Societal } & Stereotypes about women's capabilities & $\begin{array}{l}\text { Misperceptions of both Middle Eastern and North American women that they are ill- } \\
\text { equipped to handle global work abroad and domestically because of stereotypical gender } \\
\text { roles (e.g. women as homemakers and mothers). }\end{array}$ \\
\hline & $\begin{array}{l}\text { Cultural constraints for women's } \\
\text { participation at work }\end{array}$ & $\begin{array}{l}\text { Lack of appropriate cultural accommodation for Middle Eastern women to equally } \\
\text { participate in the paid workforce }\end{array}$ \\
\hline & Women's caring responsibilities & $\begin{array}{l}\text { Necessary for both Middle Eastern and North American women to consider their primary } \\
\text { caretaker duties in relation to work commitments, which could limit their professional } \\
\text { opportunities and cause stress in the family. }\end{array}$ \\
\hline \multirow[t]{2}{*}{ Organisational } & $\begin{array}{l}\text { Gendered HRM practices within } \\
\text { organisations }\end{array}$ & $\begin{array}{l}\text { Middle Eastern women are marginalised relative to Middle Eastern men vis-à-vis selection } \\
\text { and training opportunities. North American women cite a lack of transparency in selection } \\
\text { processes for international assignments abroad and being disadvantaged by unavailability } \\
\text { to network off-hours due to family obligations. }\end{array}$ \\
\hline & $\begin{array}{l}\text { Mixed organisational support for women } \\
\text { with families }\end{array}$ & $\begin{array}{l}\text { Middle Eastern women face issues of inadequate maternity leave, lack of child care and } \\
\text { career support for their (male) "trailing" spouse on international assignments abroad. North } \\
\text { American women have more travel discretion doing global work than Middle Eastern } \\
\text { women, but can also be stigmatised for family responsibilities (e.g. pregnancy). }\end{array}$ \\
\hline
\end{tabular}




\begin{tabular}{|l|l|l|}
\hline OPPORTUNITIES & \multicolumn{1}{|c|}{ Type } & \multicolumn{1}{c|}{ Description } \\
\hline Global & Global career development & $\begin{array}{l}\text { Middle Eastern women see international experience and education as a means to transcend } \\
\text { cultural stereotypes; government ties with international organisations facilitate this. North } \\
\text { American women able to express interest in and request global career to managers and be } \\
\text { considered for opportunities. }\end{array}$ \\
\hline Societal & Strong female role models & $\begin{array}{l}\text { Exposure to key women leaders critical to help Middle Eastern women, however, varies by } \\
\text { social class. }\end{array}$ \\
\hline & Support from families & $\begin{array}{l}\text { Having spouse's support important for both Middle Eastern and North American women. } \\
\text { Careers in North American couples were more often equally prioritised vs. Middle Eastern } \\
\text { couples. International assignment abroad seen as beneficial to family as a whole, especially } \\
\text { children. }\end{array}$ \\
\hline Governmental & $\begin{array}{l}\text { Government legislation and support for } \\
\text { women }\end{array}$ & $\begin{array}{l}\text { Middle Eastern women emphasised strong role that government legislation and training } \\
\text { programs can play in shaping women as global leaders. }\end{array}$ \\
\hline Organisational & Organisational support for women at work & $\begin{array}{l}\text { Both Middle Eastern and North American women can benefit from availability of flexible } \\
\text { work policies to support work-life balance and HR programs to foster global career } \\
\text { development. }\end{array}$ \\
\hline & Organisational training and development & $\begin{array}{l}\text { Middle Eastern women can benefit from increased cross-cultural training to facilitate } \\
\text { global work that is properly scheduled in accordance with cultural activities (e.g. religious } \\
\text { holidays). }\end{array}$ \\
\hline
\end{tabular}

